Louisiana State University

LSU Digital Commons

$4-1-2014$

\title{
Genetic variation among western populations of the Horned Lark (Eremophila alpestris) indicates recent colonization of the Channel Islands off southern California, mainland-bound dispersal, and postglacial range shifts
}

\author{
Nicholas A. Mason \\ San Diego State University \\ Pascal O. Title \\ San Diego State University \\ Carla Cicero \\ University of California, Berkeley \\ Kevin J. Burns \\ San Diego State University \\ Rauri C.K. Bowie \\ University of California, Berkeley
}

Follow this and additional works at: https://digitalcommons.Isu.edu/biosci_pubs

\section{Recommended Citation}

Mason, N., Title, P., Cicero, C., Burns, K., \& Bowie, R. (2014). Genetic variation among western populations of the Horned Lark (Eremophila alpestris) indicates recent colonization of the Channel Islands off southern California, mainland-bound dispersal, and postglacial range shifts. Auk, 131 (2), 162-174. https://doi.org/10.1642/AUK-13-181.1

This Article is brought to you for free and open access by the Department of Biological Sciences at LSU Digital Commons. It has been accepted for inclusion in Faculty Publications by an authorized administrator of LSU Digital Commons. For more information, please contact ir@lsu.edu. 


\title{
Genetic variation among western populations of the Horned Lark (Eremophila alpestris) indicates recent colonization of the Channel Islands off southern California, mainland-bound dispersal, and postglacial range shifts
}

\author{
Nicholas A. Mason, ${ }^{1,2, a *}$ Pascal O. Title, ${ }^{1, b}$ Carla Cicero, ${ }^{2}$ Kevin J. Burns, ${ }^{1}$ and Rauri C. K. Bowie ${ }^{2,3}$ \\ 1 Department of Biology, San Diego State University, San Diego, California, USA \\ 2 Museum of Vertebrate Zoology, University of California, Berkeley, California, USA \\ ${ }^{3}$ Department of Integrative Biology, University of California, Berkeley, California, USA \\ ${ }^{a}$ Current address: Department of Ecology and Evolutionary Biology, Cornell University, Ithaca, New York, USA \\ ${ }^{\mathrm{b}}$ Current address: Department of Ecology and Evolutionary Biology, University of Michigan, Ann Arbor, Michigan, USA \\ * Corresponding author: nam232@cornell.edu
}

Received December 30, 2013; Accepted December 31, 2013; Published March 5, 2014

\begin{abstract}
The Channel Islands off the coast of southern California host $>50$ species of terrestrial vertebrates with varying degrees of phenotypic differentiation. However, most organisms that breed on the Channel Islands remain unstudied with respect to genetic differentiation from mainland populations. By comparing patterns of genetic variation between the Channel Islands and the mainland, we aimed to further our understanding of the role that the Channel Islands have played in diversification of the North American biota. We evaluated long-standing, untested hypotheses regarding colonization patterns and evolutionary relationships among western populations of the Horned Lark (Eremophila alpestris), including the endemic Channel Island subspecies E. a. insularis. We also examined how many times Horned Larks have colonized the Channel Islands, whether the species exhibits asymmetrical patterns of gene flow between mainland and island populations, and whether E. a. strigata of the Pacific Northwest is closely related to the phenotypically similar, but geographically separated, island subspecies. We found that $E$. $a$. insularis is polyphyletic, which suggests either multiple colonization events from the mainland or incomplete lineage sorting of a large ancestral population. We also inferred higher rates of migration from the Channel Islands to the mainland, with E. $a$. strigata being closely related to individuals from the Channel Islands and coastal southern California. Moreover, ecological niche models for E. a. strigata identified suitable abiotic conditions in southern California and the Pacific Northwest during the Last Glacial Maximum, which suggests that $E$. $a$. strigata experienced a postglacial range shift in addition to a population bottleneck. Our results provide novel insight regarding the origins of the Channel Island avifauna and the evolutionary history of the Horned Lark in the western United States. Moreover, our findings suggest that Channel Island birds may be weakly differentiated from mainland populations despite phenotypic differences between recognized subspecies.
\end{abstract}

Keywords: Alaudidae, Eremophila alpestris, glacial refugia, mitochondrial DNA, niche modeling, phylogeography

\section{RESUMEN}

Las Islas del Canal, en la costa sur de California, albergan más de 50 especies de vertebrados terrestres con varios grados de diferenciación fenotípica. Sin embargo, aún no se ha estudiado la diferenciación genética de la mayoría de los organismos que se reproducen en estas islas con respecto a tierra firme. Mediante la comparación de los patrones de diferenciación genética entre las poblaciones insulares y las de tierra firme queremos aumentar nuestro conocimiento sobre el papel que han desempeñado estas islas en la diversificación de la biota Norteamericana. Evaluamos hipótesis que no habían sido probadas con respecto a los patrones de colonización y las relaciones evolutivas entre poblaciones occidentales de Eremophila alpestris, incluyendo la subespecie endémica de las Islas del Canal, E. a. insularis. Además examinamos cuántas veces $E$. alpestris ha colonizado dichas islas, si existe flujo genético asimétrico entre las poblaciones del continente y las insulares, y si $E$. a. strigata, del noreste del Pacífico, está cercanamente relacionada con la subespecie insular, que es fenotípicamente similar pero está separada geográficamente. Encontramos que E. a. insularis es un taxón polifilético, lo que sugiere múltiples eventos de colonización desde el continente o que no se ha dado la separación completa de linajes de una población ancestral grande. También inferimos altas tasas de migración desde las islas hacia el continente, de modo que E. a. strigata está cercanamente relacionada con los individuos de las islas y de la costa sur de California. Además, modelos de nicho 
ecológico de E. a. strigata identificaron condiciones abióticas apropiadas para su presencia en el sur de California y en el noroccidente del Pacífico durante el Último Máximo Glacial, lo que sugiere que $E$. a. strigata experimentó un cambio post-glacial de su distribución geográfica junto con un cuello de botella poblacional. Nuestro estudio provee una nueva visión sobre los orígenes de la avifauna de las Islas del Canal y sobre la historia evolutiva de $E$. alpestris en el occidente de los Estados Unidos. Además, nuestros resultados sugieren que las aves de estas islas podrían estar débilmente diferenciadas genéticamente de las poblaciones continentales a pesar de las diferencias fenotípicas entre las subespecies reconocidas.

Palabras clave: Alaudidae, Eremophila alpestris, refugios glaciales, ADN mitocondrial, modelamiento de nicho, filogografía

\section{INTRODUCTION}

The study of islands has provided great insight into evolutionary processes and patterns that underlie differentiation within and among species (Losos and Ricklefs 2009). During the Pleistocene epoch, glacial cycles effected dramatic changes in the size, topography, and degree of isolation among island formations, which has influenced patterns of population differentiation and speciation among members of the North American avifauna (Johnson 1972, Avise and Walker 1998, Clark et al. 2009). The Channel Islands are a chain of eight islands divided into two groups (Northern and Southern) that are located off the coast of southern California, USA. These islands vary in size and degree of isolation from the mainland (Schoenherr et al. 1999) and may have acted as a glacial refugium during the Last Glacial Maximum (LGM; Johnson 1977). Of the 41 species of land birds known to breed on the Channel Islands, 1 is an endemic species and 13 have endemic subspecies (Johnson 1972, Rea 1991). However, only 3 species have been studied with respect to genetic differentiation from the mainland: the Island Scrub-Jay (Aphelocoma insularis; Delaney et al. 2008), the San Clemente Loggerhead Shrike (Lanius ludovicianus mearnsi; Caballero and Ashley 2011), and the Channel Island Song Sparrow (Melospiza melodia graminea; Wilson et al. 2009). Thus, the degree of genetic differentiation among the remaining avifauna of the Channel Islands is still unknown.

The Horned Lark (Eremophila alpestris), one of the species that has yet to be studied, is a widespread passerine with 42 currently recognized subspecies and is the only native alaudid in North America. An endemic island subspecies (E. a. insularis) breeds on each of the eight main Channel Islands, and E. $a$. actia breeds on the adjacent mainland (Oberholser 1902, Beason 1995). Based on the presence of a single, well-differentiated subspecies on the island chain, Johnson (1972) hypothesized that Horned Larks colonized the Channel Islands through a single colonization event to the Northern Channel Islands. Johnson (1972) also hypothesized greater gene flow from the islands to the mainland than vice versa, based on the presence of specimens with $E$. a. insularis phenotypes on the mainland and regular observations of mainland-bound dispersal (Grinnell and Miller 1944). Although this anecdotal evidence suggests asymmetrical gene flow between island and mainland populations, this hypothesis has not been tested within a coalescent framework (Knowles and Carstens 2007).

Behle (1942) performed a detailed study of phenotypic differentiation among Horned Lark subspecies of the western United States and identified numerous phenotypic similarities between $E$. $a$. insularis of the Channel Islands and E. a. strigata of the Pacific Northwest, which led Behle (1942) to hypothesize a close relationship between these two taxa. The island subspecies breeds in open, windswept, grassy areas that are often cloaked in fog, whereas $E$. $a$. strigrata breeds throughout cool, damp pastures and open grasslands in the lowlands of western Washington and Oregon. Eremophila a. strigata is restricted to the Pacific Northwest, and surveys have confirmed that it has been extirpated from much of its historical breeding grounds; it is now classified as a taxon of conservation concern (Pearson and Altman 2005). The current distribution of $E$. a. strigata closely resembles that of Douglas-fir (Pseudotsuga menziesii), and paleobotanical evidence of Pseudotsuga specimens from Santa Cruz Island led Behle (1942) to hypothesize a biogeographic relationship between $E$. $a$. insularis and E. a. strigata. More recently, Drovetski et al. (2005) found that E. a. strigata experienced a severe population bottleneck and is more closely related to individuals from California than to more geographically proximate populations in eastern Washington. Thus, the current abiotic conditions that characterize the breeding range of E. a. strigata may have existed in regions of coastal California and the Channel Islands during the LGM, which could underlie a shared evolutionary history and their phenotypic similarity; however, the present and LGM abiotic niches of $E$. a. strigata have not yet been modeled.

Here, we use molecular data to test the hypotheses first postulated by Johnson (1972) that (1) E. a. insularis colonized the Channel Islands through a single event and (2) gene flow is asymmetrical between mainland and island populations. We also test Behle's (1942) hypothesis that $E$. a. insularis and E. a. strigata are closely related. Finally, we quantify the abiotic conditions that characterize the current distribution of $E$. a. strigata and compare current 
niche models to projected historical models of the LGM to evaluate Behle's (1942) hypothesis that E. a. strigata was distributed throughout the Channel Islands and coastal regions of central and southern California during the LGM.

\section{METHODS}

\section{Taxonomic and Molecular Sampling}

We extracted genomic DNA from tissues using a DNAeasy kit, following the recommendations of the manufacturer (Qiagen, Valencia, California, USA), and sequenced the mitochondrial gene region ND2 from frozen tissues of 144 individuals (Figure 1; GenBank accession nos. KF743558-KF743700) using the primers L5215 (TATCGGGCCCATACCCCGAAAAT; Hackett 1996) and H5578 (CCTTGAAGCACTTCTGGGAATCAGA; Hackett 1996). To supplement our sampling, we also added 100 sequences from Drovetski et al. (2005; GenBank accession nos. DQ187388-DQ187487). Thus, we included a total of 244 individuals in the study; additional detailed information on sample sizes and specific localities can be found in the Supplementary Material Table S1. We used Sequencher version 3.7 (Gene Codes, Ann Arbor, Michigan, USA) to align and check overlapping sequences by eye.

\section{Phylogenetic Analyses}

We performed phylogenetic reconstructions using maximum likelihood (ML) and Bayesian analyses. Alström et al. (2013) demonstrated that Temminck's Lark (E. bilopha) is sister to E. alpestris, and thus we used an individual ND2 sequence of E. bilopha from Zink et al. (2008) as the outgroup to $E$. alpestris (GenBank accession no. EU307808.1) for all analyses. We also used two individuals from Russia as an outgroup to New World populations of E. alpestris. We inferred an ML tree using RAxML version 7.3.2 (Stamatakis 2006, Stamatakis et al. 2008) on the CIPRES portal, wherein we estimated the best tree and performed rapid bootstrapping within the same run under the assumed GTR $+\Gamma$ model. We identified the best-fit model of nucleotide substitution for each codon position using Akaike's Information Criterion (AIC) in jModeltest version 0.1.1 (Posada 2008). We then used MrBayes version 3.1.2 (Huelsenbeck and Ronquist 2001, Ronquist and Huelsenbeck 2003) to implement two runs partitioned by codon position with four chains each for 2 million generations. Trees were sampled every 1,000 generations. We assessed stationarity using Tracer version 1.5 (Drummond and Rambaut 2007) and by ensuring that effective sample sizes were above a threshold of 200 .

A likelihood ratio test demonstrated that the data were sufficiently clock-like $(-2 \Delta \operatorname{lnL}=202.02, \mathrm{df}=242, P>0.9)$ to employ a strict molecular clock in BEAST version 1.7.2 (Drummond and Rambaut 2007). We set the prior to follow a normal distribution, with a mean substitution rate (ucld mean) of $0.029 \mathrm{Ma}^{-1}$ and a standard deviation of $0.003\left(95 \% \mathrm{HPD}=2.3-3.3 \times 10^{-2}\right)$, based on comparisons of Hawaiian Honeycreeper sequence divergence and known ages of the Hawaiian Islands (Lerner et al. 2011). We partitioned the data by codon position and implemented the HKY $+\mathrm{I}+\Gamma$ model. The tree prior was set for constant population size. We ran three independent runs of 20 million generations, sampled trees every 2,000 generations, and confirmed stationarity with Tracer. We ran AWTY (Nylander et al. 2008) to confirm convergence in topology, combined post-burn-in runs using LogCombiner, and inferred a maximum clade credibility tree using TreeAnnotator (Drummond and Rambaut 2007).

\section{Population Genetics Analyses}

We constructed a haplotype network for all individuals using statistical parsimony in TCS version 1.2.1 (Clement et al. 2000) and visualized the network using the "pegas" package in $\mathrm{R}$ (Paradis 2010). In addition, we examined how molecular variation is partitioned between Channel Island and mainland populations from southern California by performing an analysis of molecular variance (AMOVA; Excoffier et al. 1992) and calculating pairwise $F_{\mathrm{ST}}$ values using Arlequin version 3.5 (Excoffier and Lischer 2010). We used IMa2 version 2.0 (Hey 2010) to estimate directional gene flow and splitting times between Channel Island and mainland populations within a coalescent framework. To fully explore the hypotheses proposed by Behle (1942) and Johnson (1972), and to account for the potential confounding influence of ancestral polymorphism, we implemented two nested models within IMa2. The first model sought to determine whether or not we could reject a model with migration rates constrained to zero between Channel Island and mainland populations, and the second model constrained migration rates between Channel Island and mainland populations to be equal. For ancestral polymorphism to be a likely explanation for shared haplotypes between mainland and island populations, we would expect to be unable to reject a model of zero recurrent gene flow between these populations.

\section{Ecological Niche Modeling of E. a. strigata}

We downloaded 239 occurrence records for E. a. strigata from the ORNIS2 Web portal (see Acknowledgments), of which 212 were georeferenced. If records included a georeferencing uncertainty, we discarded any records with a maximum uncertainty $>5 \mathrm{~km}$. We then plotted occurrence records against the known distribution of the subspecies (BirdLife International and NatureServe 2012) and kept only points found within a $1^{\circ}$ buffer of the range and with unique coordinates.

We downloaded current and historical climatic data from the WorldClim database (Hijmans et al. 2005) in the 


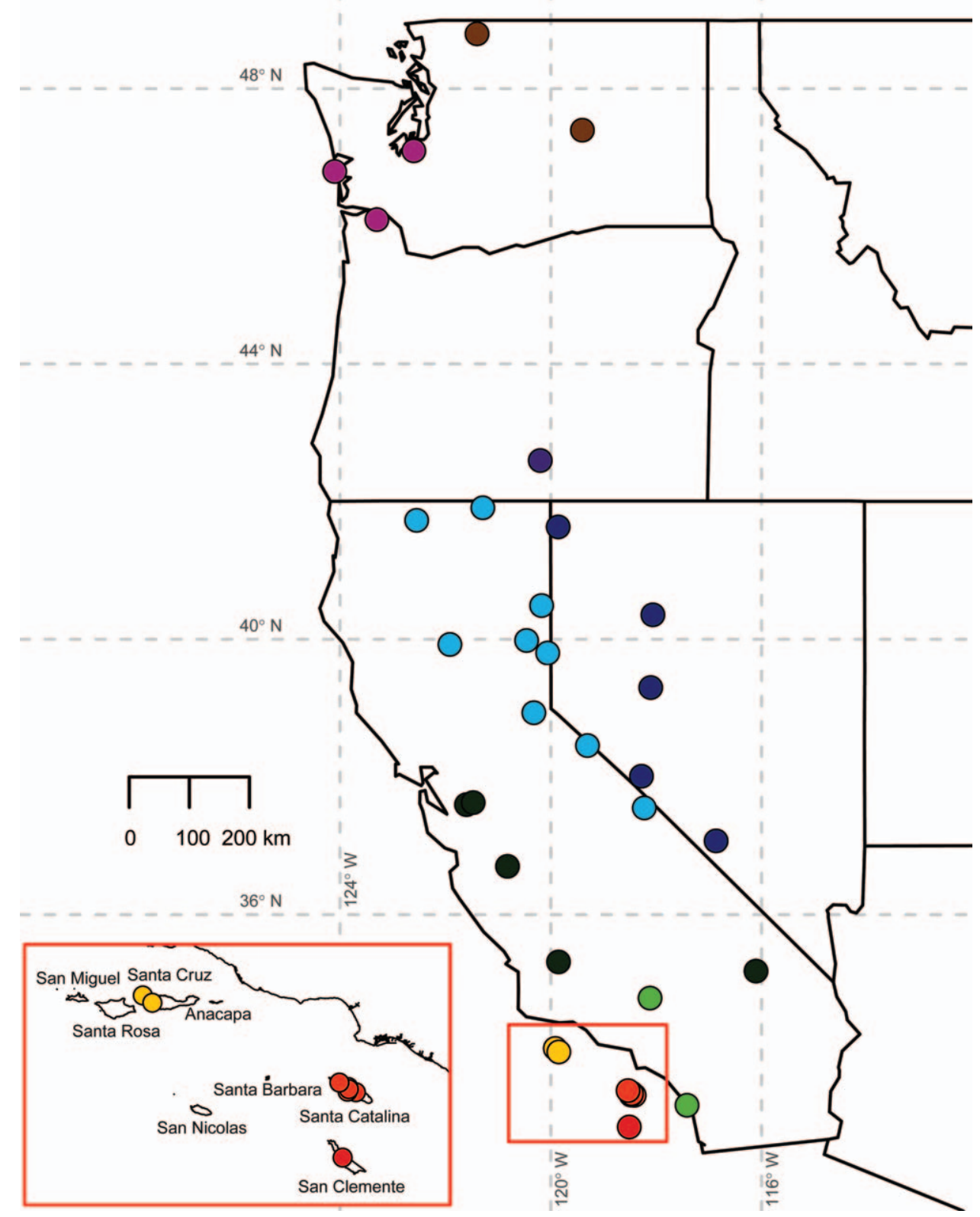

FIGURE 1. Map depicting the localities of Horned Larks sampled for this study; some dots represent more than one individual per locality. Colors of dots correspond to the key in Figures 2 and 3. Inset displays detail of sampling localities in the Channel Islands, USA. Sampling localities in Alaska, USA; Oklahoma, USA; Colorado, USA; and Russia are not shown.

form of 19 bioclimatic variables with a resolution of 2.5 arcminutes, which translates to $\sim 5 \mathrm{~km}$ and matches the uncertainty cutoff of the locality data. Historical climate data represent the LGM (21,000 yr B.P.) for two climate models: CCSM (Collins et al. 2006) and MIROC (Hasumi and Emori 2004). We manipulated all raster data using the "raster" package in R (Hijmans and van Etten 2012) and filtered out any points that fell outside of the environmental raster cells (e.g., points on the coast that fell into the ocean).

To account for correlation between bioclimatic variables, we calculated pairwise correlation coefficients between variables and removed redundant variables until no two variables had a correlation coefficient $>0.75$. After accounting for autocorrelation, we retained eight variables with a mean correlation coefficient of 0.36 . These variables included mean diurnal range (mean of monthly [max temp - min temp]), isothermality (mean diurnal range / annual temperature range), temperature annual range, mean temperature of the wettest quarter, precipitation of the wettest month, precipitation of the driest month, precipitation seasonality, and precipitation of the coldest quarter. 


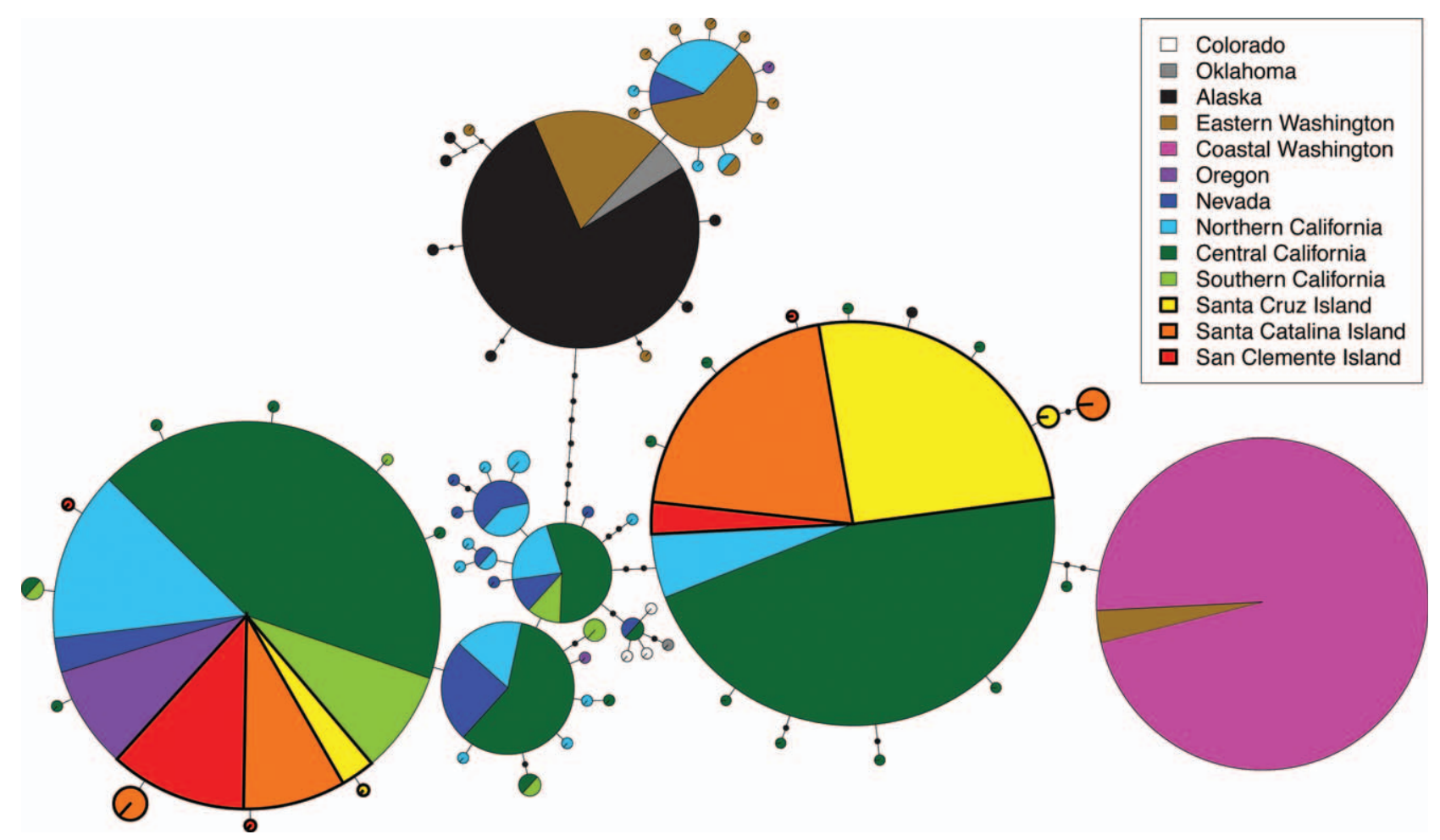

FIGURE 2. Haplotype network of 75 ND2 haplotypes from 244 individual Horned Larks (European samples not shown), with geographic areas indicated by color. Unsampled haplotypes are represented by small black dots. Channel Island individuals are outlined in bold. The number of individuals that share a given haplotype is proportional to the diameter of each haplotype.

We modeled the current climatic niche of E. a. strigata with Maxent version 3.3.3k (Phillips et al. 2006, Phillips and Dudík 2008) and the "Dismo" package (Hijmans et al. 2012) in R, using default settings. Our attempts to optimize the beta multiplier (Warren and Seifert 2011) in Maxent across multiple values $(0.5,1,3,5,7,9,11,13,15$, 17 , and 19) returned the default value of 1 as being best, as compared with AIC corrected for small sample size $\left(\mathrm{AIC}_{\mathrm{c}}\right)$. We defined the region used to train the niche model with a custom function in $\mathrm{R}$ that determined which ecoregions included E. a. strigata and buffered those by $10^{\circ}$ (Olson et al. 2001, Barve et al. 2011). From this initial niche model, we discarded $5 \%$ of the points with the lowest probability of occurrence and created a new niche model with $95 \%$ of the original occurrence points. Thus, we conservatively removed occurrences that could be flawed for a number of reasons, including species misidentification or georeferencing error. We validated the current climate niche model using an area-under-the-curve (AUC) of the receiveroperating-characteristic (ROC) approach (Peterson et al. 2008), developed in R, that employs latitudinal, spatially structured partitioning to evaluate the data (Peterson et al. 2011). We ran a total of 200 iterations with $50 \%$ resampling of the test data, with an omission threshold of $5 \%$. If $95 \%$ of the iterations produced an AUC ratio $>1$, we accepted the niche model. Partial AUC model validation returned a median AUC ratio of 1.99, with no iterations falling below 1. Our final data set included 46 unique localities from specimen records in the following collections (Supplementary Material Table S2): Beatty Biodiversity Collection, University of British Columbia (UBCBBM); Delaware Museum of Natural History (DMNH); Museum of Comparative Zoology, Harvard (MCZ); Museum of Vertebrate Zoology, UC Berkeley (MVZ); Royal Ontario Museum (ROM); San Diego Natural History Museum (SDNHM); Santa Barbara Museum of Natural History (SBMNH); University of California, Los Angeles (UCLA); University of Michigan Museum of Zoology (UMMZ); and Yale University Peabody Museum (YPM). Once the current niche model passed validation, it was projected to the two historical climate models. We visualized historical models with the Maxent default continuousprobability output as well as with a binary least-trainingpresence thresholding output.

\section{RESULTS}

\section{Phylogenetic Analyses}

We inferred 76 distinct haplotypes among the 244 individuals included in the study (Figure 2). The two most common haplotypes occurred in $14.3 \%(n=35)$ and $13.1 \%$ $(n=32)$ of all individuals, respectively, and $24.2 \%(n=59)$ 


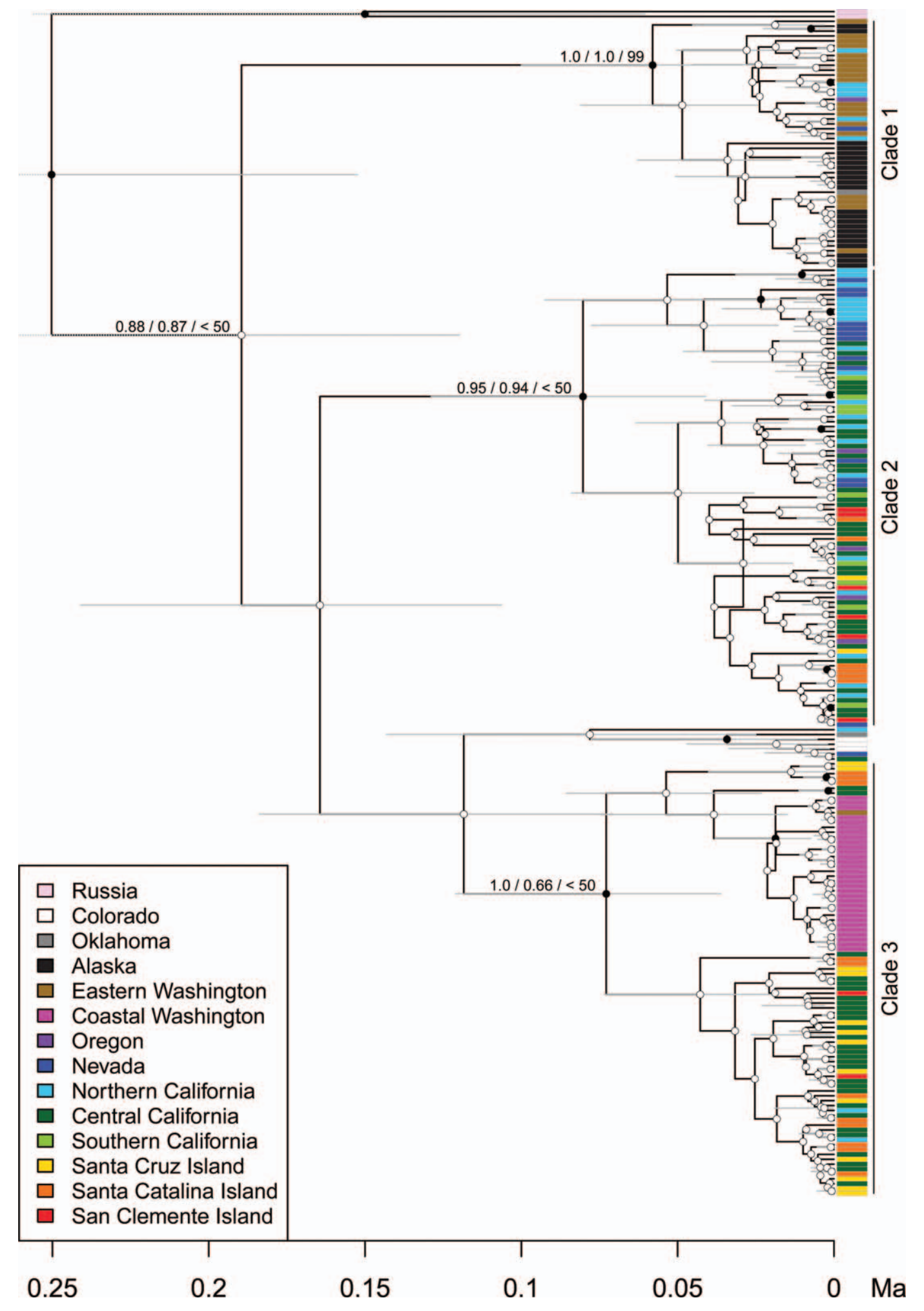

FIGURE 3. Time-calibrated phylogeny of relationships among western North America populations of Eremophila alpestris as inferred with BEAST. Divergence times were estimated using a strict molecular clock and are shown on the bottom in millions of years before present. Gray bars indicate the HPD intervals for the divergence times of each node. Black and white nodes refer to strong ( $\geq 0.95$ PP) and weak nodal support ( $\leq 0.95$ PP) from the BEAST analysis, respectively. Posterior probabilities from BEAST, MrBayes, and maximumlikelihood bootstrap values are displayed in this order for clades that are referenced in the text. Geographic areas are indicated by color. The outgroup (E. bilopha) was included in the BEAST analysis but was omitted from this figure to improve visualization. 

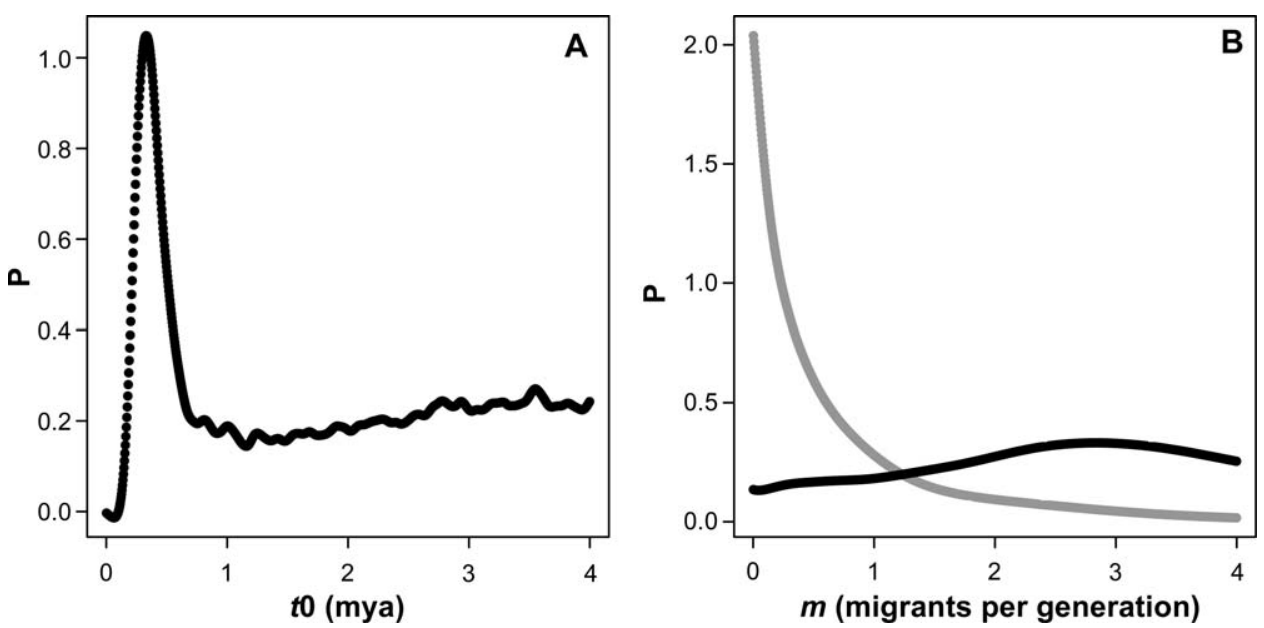

FIGURE 4. Estimates of (A) splitting time (mya) between mainland and island Horned Lark populations and (B) directional gene flow (migrants per generation) from mainland to Channel Islands (gray) and from Channel Islands to the mainland (black), inferred within a coalescent framework using IMa2.

of individuals were singletons with unique ND2 sequences (Figure 2). The maximum uncorrected distance among ingroup taxa was $2.07 \%$. Of the 90 segregating sites observed across 1,041 bp of ND2, 12 were first-position, 6 were second-position, and 72 were third-position substitutions. The HKY, F81, and TnR were the best-fit models of nucleotide substitution for the first, second, and third codon positions, respectively. The ML and Bayesian analyses were largely congruent, although node support differed among inference methods (Supplementary Material Figure S1).

All analyses recovered $E$. alpestris as monophyletic with respect to its sister species $E$. bilopha. However, we did not infer strong support for the monophyly of a New World $E$. alpestris lineage with respect to Old World samples (BEAST posterior probability $[\mathrm{PP}]=0.88$, MrBayes $\mathrm{PP}=$ 0.87 , ML bootstrap $[\mathrm{BS}]<50 \%$ ). Among populations in the Western Hemisphere, our BEAST analysis recovered three strongly supported clades near the root of the phylogeny (Figure 3). Within these clades, individual haplotypes were generally separated by a small number of mutations, which reflects the low level of divergence among individuals within these groups (Figure 2). Clade 1 included mostly individuals sampled from Alaska and eastern Washington and was strongly supported in our BEAST (BEAST PP $=1.0$ ), MrBayes (1.0 PP), and ML analyses $(99 \% \mathrm{BS})$. Clade $2(\mathrm{BEAST} \mathrm{PP}=0.95)$ contained one-third of the individuals sampled from the Channel Islands, including six of the eight individuals sampled from San Clemente Island, as well as individuals from southern and northern mainland California and Nevada. Clade 2 was not statistically supported in either the MrBayes ( $\mathrm{PP}=$ 0.94 ) or ML analyses (BS $<50 \%$ ). Clade 3 included all individual E. a. strigata of coastal Washington, individuals from central and southern California, and two-thirds of the individuals sampled from the Channel Islands, including 24 of the 31 individuals sampled from Santa Cruz Island and Santa Catalina Island. This clade was strongly supported in the BEAST analyses $(\mathrm{PP}=1.0)$ but lacked statistical support in our MrBayes (PP 0.66) and ML (BS < $50 \%$ ) analyses. The relationships among these three clades were not well resolved. Each clade was largely geographically concordant, with the exception that two individuals from Oklahoma shared their haplotype with individuals from Alaska and eastern Washington.

\section{Population Genetics Analyses}

Differences in the genetic composition between the Channel Islands and mainland southern California regions accounted for $26.3 \%$ of the overall molecular variance $\left(F_{\mathrm{CT}}\right.$ $=0.263, P=0.31$ ). Comparisons among populations within these two groups explained $14.28 \%$ of the molecular variance $\left(F_{\mathrm{SC}}=0.194, P=0.009\right)$, and variation among all populations accounted for $59.42 \%\left(F_{\mathrm{ST}}=0.406, P<\right.$ 0.0001). Uncorrected pairwise genetic distances between the Channel Island and southern California mainland populations ranged from $0 \%$ to $0.9 \%$.

Using IMa2, we estimated the splitting time between mainland and Channel Island populations to have occurred 0.31 mya (95\% HPD interval: 0.166-3.998; Figure $4 \mathrm{~A})$. The estimated current migration rate (Figure $4 \mathrm{~B}$ ) from the mainland to the Channel Islands $\left(\mathrm{m}_{\mathrm{M} \rightarrow \mathrm{CI}}=0\right.$, 0-2.602) was lower than that from the Channel Islands to the mainland $\left(\mathrm{m}_{\mathrm{CI}} \rightarrow \mathrm{M}=2.834,0.35-3.998\right)$. Using likelihood ratio tests, we were unable to reject the following models: Both gene-flow parameters constrained to zero $\left(\chi^{2}=3.8, \mathrm{df}=2, P=0.15\right)$, gene flow from the Channel Islands to mainland populations constrained to 


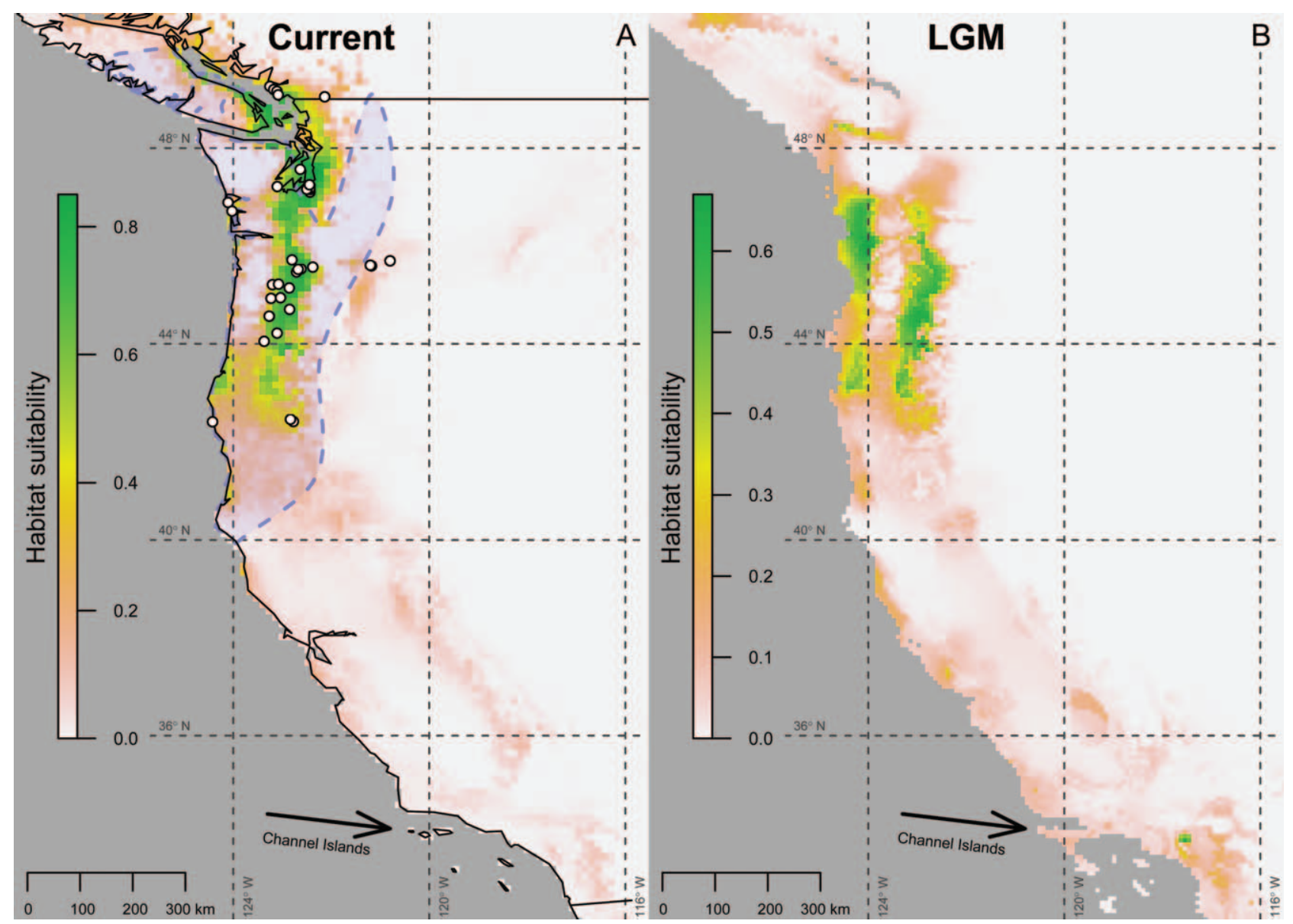

FIGURE 5. (A) Current ecological niche models of Eremophila alpestris strigata. Colored cells represent habitat suitability as indicated by the scale on the left. White dots represent occurrence localities used to construct both current and historical niche models. The current distribution of this subspecies is shown by a dashed blue line (BirdLife International). Black arrow indicates the location of the Channel Islands. (B) CCSM historical ecological niche models of Last Glacial Maximum (LGM; 21,000 yr B.P.) for this subspecies. Black arrow indicates location of the Channel Islands.

zero $\left(\chi^{2}=3.2, \mathrm{df}=1, P=0.09\right)$, or gene flow from the mainland to the Channel Island populations constrained to zero $\left(\chi^{2}=0, \mathrm{df}=1, P=1.0\right)$. However, we were able to reject a model in which gene-flow parameters between populations were constrained to be equal $\left(\chi^{2}=3.7, \mathrm{df}=1\right.$, $P=0.05)$.

\section{Ecological Niche Modeling of E. a. strigata}

The current climate niche model for $E$. $a$. strigata shows a potential distribution that is limited to the northwest coast of North America, with some marginally suitable habitat to the south of its current range (Figure 5A). Both of the historical climate models projected coastal regions of the Pacific Northwest to be highly suitable during the LGM and also exhibited regions of moderate suitability along the Sierra Nevada mountain range and coastal southern California (Figure 5B). A detailed look at the Channel Islands and corresponding coastal regions suggested that the Channel Islands may not have been highly suitable for
E. a. strigata, although the MIROC model suggested that the islands were marginally suitable. By contrast, a small area on the mainland was predicted to have been highly suitable, as indicated by a small cluster of green pixels in what is now Riverside County, California. Precipitation of the coldest quarter was the abiotic variable that contributed most to habitat suitability for E. a. strigata (63\%).

\section{DISCUSSION}

Our results provide novel insight into the phylogeographic structure and evolutionary history of the Horned Lark in the western United States and the Channel Islands. The lack of monophyly among individual E. a. insularis sampled in our study presents two alternative interpretations: (1) multiple recent colonization events have occurred; or (2) several individuals with different mitochondrial genotypes colonized the Channel Islands recently, and incomplete lineage sorting has precluded 
reciprocal monophyly between $E$. a. insularis and mainland populations. Dispersal from the Channel Islands to the mainland, as proposed by Johnson (1972), could lead to secondary homogenization with mainland populations and further complicate distinguishing between these alternative hypotheses. It is important to note that our findings are based on a single locus that may not reflect genomewide patterns of genetic variation among populations (Edwards 2009). However, mtDNA is recognized as a "leading indicator" of population divergence due to a smaller effective population size (Zink and Barrowclough 2008). Therefore, we expect that variation among nuclear loci also will reflect the shallow divergence between mainland and Channel Island populations that we inferred here. A multilocus study with increased sampling will likely provide further information regarding colonization patterns and current levels of gene flow between western Horned Lark populations.

Multiple independent colonizations of islands are not uncommon in passerines that are capable of long-distance dispersal. For example, Ryan et al. (2013) found that tanager-finches in the genera Rowettia and Nesospiza arrived on the extremely remote Tristan de Cunha and Gough islands in the South Atlantic Ocean via separate colonization events. Our BEAST tree recovered multiple clades containing individual E. a. insularis, which may provide some evidence of multiple colonizations. However, the ML and Bayesian (MrBayes) inferences failed to recover these relationships with strong support. Furthermore, several recent studies have demonstrated that islands can act as the origin of mainland radiations (e.g., Filardi and Moyle 2005), which suggests that islands may not always be the sinks they are traditionally perceived to be. Such studies have centered on tropical taxa, and relatively little is known about whether temperate islands could act as a source of mainland colonists, a result that would be consistent with Johnson's (1972) hypothesis of asymmetrical dispersal between Channel Island and mainland Horned Lark populations.

The Horned Lark typically occurs in flocks of 10-25 individuals, although flocks can reach many hundreds of individuals outside of the breeding season and during phases of inclement weather (Beason 1995). Therefore, the possibility that a large flock colonized the Channel Islands during a single colonization event is feasible. This hypothesis also is consistent with the morphological diagnosibility of the Channel Island taxon E. a. insularis (Behle 1942), as well as our IMa2 analyses, wherein our nested model analyses could not reject zero recurrent gene flow from the mainland to the Channel Islands. By contrast, we were able to reject a nested model of symmetrical gene flow between island and mainland populations. This result is consistent with Johnson's (1972) hypothesis that the Horned Lark exhibits asym- metrical gene flow, with greater dispersal from the Channel Islands to the mainland than vice versa, as well as the direct observation of overwater dispersal from island to mainland populations (Grinnell and Miller 1944). Thus, the sharing of haplotypes between Channel Island and mainland populations is likely a consequence both of $E$. $a$. insularis acting as a source population of migrants to the mainland and of incomplete lineage sorting (ancestral polymorphism), especially given the recent age of Channel Island populations ( 0.17 mya; Figure 3$)$.

In support of this idea, $>100 \mathrm{yr}$ of grazing by introduced goats has converted much of the native island scrub to a more barren, open landscape that is favored by $E$. $a$. insularis (Schoenherr et al. 1999). This habitat conversion, combined with the island's reduced predation pressure, may have created favorable breeding conditions over the past century. However, recent efforts to remove invasive herbivores have helped the native vegetation recover (Laughrin et al. 1994), which may limit the amount of suitable habitat for E. a. insularis in the future and thereby encourage mainland-bound dispersal if the island population has approached its carrying capacity. Many specimens that bear a phenotypic resemblance to $E$. $a$. insularis have been collected from mainland California (Behle 1942, Patten et al. 2003, N. A. Mason personal observation), but additional banding data or observations of nesting behavior by $E$. a. insularis on mainland California could provide decisive evidence in support of increased mainland-bound dispersal and directional gene flow in the Horned Lark.

It is important to note that Horned Larks occur on all eight of the Channel Islands, and sampling of other island populations may reveal additional phylogeographic complexity. The Northern Channel Islands are not separated by large geographic distances, and they all formed a single landmass during the LGM. Thus, unsampled populations from Santa Rosa, Anacapa, and San Miguel islands may not be well differentiated from individuals that were sampled from Santa Cruz. By contrast, San Nicolas in the Southern Channel Islands is the most remote of the eight islands and is also much smaller than any of the three islands included in the present study. Accordingly, the San Nicolas population may have lower genetic diversity and a smaller effective population size. If a lack of lineage sorting from a large ancestral population accounts for a large portion of the shared alleles between mainland and island populations, we may expect more rapid fixation of alleles on San Nicolas as a consequence of genetic drift, compared with populations of $E$. $a$. insularis on the other Channel Islands.

Comparative Phylogeography of Channel Island Taxa The Horned Lark is widely distributed, with multiple geographically disjunct populations, which suggests that 
these populations are capable of dispersing across large distances (Lester et al. 2007). Thus, the distance between the Channel Islands and the mainland (about $18-33 \mathrm{~km}$ minimum for northern and southern islands, respectively) may not represent a significant barrier to gene flow between island and mainland Horned Lark populations compared with other birds. Unlike the insular subspecies of Horned Lark, the Island Scrub-Jay shares no mtDNA haplotypes $\left(F_{\mathrm{ST}}=0.901\right)$ with its closest relative, the Western Scrub-Jay (Aphelocoma californica), which suggests substantial differentiation and little or no ongoing gene flow (Delaney and Wayne 2005). Likewise, the San Clemente Loggerhead Shrike shares few haplotypes with mainland populations, with an $F_{\mathrm{ST}}$ value of 0.544 between San Clemente and neighboring San Diego populations (Mundy et al. 1997). In another shrike study, Caballero and Ashley (2011) increased the number of individuals sampled and did not find significant differentiation in mtDNA control-region variation, but did find significant differentiation among seven microsatellite loci among the mainland, Southern Channel Islands, and Northern Channel Islands. Finally, Channel Island Song Sparrows have unique, monophyletic haplotypes compared with mainland populations, and also share no haplotypes between the Northern and Southern island groups (Wilson 2008). Furthermore, allelic richness is $18 \%$ lower among Song Sparrows from the Northern Channel Islands compared with mainland individuals and decreases among islands with increasing distance from the mainland (Wilson et al. 2009).

The Horned Lark also appears to be less differentiated than many of the nonavian vertebrates from the Channel Islands that have been studied to date. Comparisons between mainland gray fox (Urocyon cinereoargenteus) and island fox (U. littoralis) populations recovered an $F_{\mathrm{ST}}$ value of 0.56 and a single colonization event (Gilbert et al. 1990, Wayne et al. 1991). Deer mice (Peromyscus maniculatus) on the Channel Islands have unique mtDNA haplotypes that suggest an evolutionary trajectory independent of mainland populations (Ashley and Wills 1987, Pergams and Ashley 2000). However, the island subspecies of the spotted skunk (Spilogale gracilis amphiala) demonstrates a level of differentiation (mean $[ \pm \mathrm{SE}] F_{\mathrm{ST}}$ of islandmainland comparisons $=0.22 \pm 0.04$; Floyd et al. 2011) that is comparable to that in the Horned Lark. Although the Horned Lark appears to be less differentiated than other taxa on the basis of $F_{\mathrm{ST}}$ values, it is important to note that this parameter is sensitive to overall marker variability and effective population size, which vary between molecular markers and systems (Hedrick 2005). This warrants a cautious interpretation of differences in $F_{\mathrm{ST}}$ values between studies.

\section{Phylogeography of the Horned Lark in the western United States}

Our BEAST analysis inferred three strongly supported clades in western North America, although these clades were not consistently recovered by MrBayes and ML analyses (Figure 3). Clade 1 contained mostly individuals from Alaska and eastern Washington and was inferred by Drovetski et al. (2005) as well. However, our increased geographic sampling revealed that individuals from disparate and more southern localities (e.g., Oklahoma and Nevada) also belonged to this clade. Shared haplotypes among geographically distant samples suggest that either widespread gene flow or incomplete lineage sorting is operating at the regional scale (Knowles and Carstens 2007). Clade 2 contained individuals from Oregon, Nevada, California (northern, central, southern), and some individuals from each of the Channel Islands that were sampled (Figure 3). The widespread haplotype sharing among localities sampled in this clade suggests frequent gene flow and admixture among mainland populations of the Horned Lark in the southwestern United States. This interpretation is corroborated by abundant phenotypic intergradation among specimens collected in southern, central, and northern California and Nevada (Behle 1942). Clade 3 contained all the individuals of $E$. a. strigata, which shared a single haplotype (Figure 3). This result confirms the findings of Drovetski et al. (2005) that E. a. strigata is well differentiated from other Horned Lark populations in western North America. Furthermore, our increased sampling revealed that $E$. a. strigata was derived from a Pacific Coast lineage that includes both coastal and Channel Island populations. Broad phylogeographic structuring between northern (i.e. Alaskan) and southwestern populations has been observed in other taxa, including the Hairy Woodpecker (Picoides villosus; Klicka et al. 2011), the Fox Sparrow (Passerella iliaca; Zink 1994), and Troglodytes species (Drovetski et al. 2004), among others. Thus, the broad-scale phylogeographic patterns observed in the Horned Lark may be typical of many North American birds.

Our projected niche models of E. a. strigata for the LGM identified a small area of modern-day Riverside County in southern California and large coastal areas of the Pacific Northwest as bioclimatically suitable, whereas the Channel Islands and parts of the Sierra Nevada were predicted as moderately suitable (Figure $5 \mathrm{~B}$ ). Variation among mtDNA sequences suggests that $E$. $a$. strigata is closely related to a widely shared haplotype that includes mostly individuals from the Channel Islands and central California (Figure 2). Therefore, E. a. strigata may have experienced a postglacial range shift whereby southern California populations either shifted their range northward or were extirpated as southern California and the Channel Islands became hotter and more arid (Oster et al. 2009). 
Many other taxa exhibit a similar northward, postglacial range shift along the Pacific Coast (Swenson and Howard 2005).

Given the phylogeographic structure observed among populations of Horned Larks in the western United States, it seems likely that a comprehensive phylogeographic study of the entire species range would reveal multiple, distinct evolutionary lineages. On the basis of a molecular clock, we estimate that all individual Horned Larks included in our study shared a common ancestor just more than 0.25 mya. Thus, a range-wide phylogeographic study of the Horned Lark could provide insight into how wide geographic distributions can evolve within short evolutionary time scales and would also facilitate a muchneeded assessment of species limits within Eremophila.

\section{ACKNOWLEDGMENTS}

We are grateful to the following institutions and individuals who provided tissue loans: the Natural History Museum of Los Angeles County (K. Garrett), the San Diego Natural History Museum (P. Unitt), and the San Diego State University Museum of Biodiversity. We thank J. Penalba and L. Smith for assistance with lab work. We benefited from the published work of S. Drovetski, S. Pearson, and S. Rohwer, and thank them for their collecting efforts and for depositing their data in GenBank. We also thank I. Lovette, D. Baldassarre, N. Chen, P. Deane, Y. Kapetenakos, S. Taylor, and other members of the Fuller Lab at the Cornell Lab of Ornithology, as well as two anonymous reviewers, for valuable feedback on the manuscript. We are grateful to all museums that provided occurrence data through the ORNIS network. N.A.M. was financially supported by the California State University Sally Casanova Predoctoral Program. The ORNIS2 Web portal is at http://ornis2.ornisnet.org/.

\section{LITERATURE CITED}

Alström, P. A., K. N. Barnes, U. Olsson, F. K. Barker, P. Bloomer, A. A. Khan, M. A. Qureshi, A. Guillaumet, P. A. Crochet, and P. G. Ryan (2013). Multilocus phylogeny of the avian family Alaudidae (larks) reveals complex morphological evolution, non-monophyletic genera and hidden species diversity. Molecular Phylogenetics and Evolution 69:1043-1056.

Ashley, M., and C. Wills (1987). Analysis of mitochondrial DNA polymorphisms among Channel Island deer mice. Evolution 41:854-863.

Avise, J. C., and D. Walker (1998). Pleistocene phylogeographic effects on avian populations and the speciation process. Proceedings of the Royal Society of London, Series B 265: 457-463.

Barve, N., V. Barve, A. Jiménez-Valverde, A. Lira-Noriega, S. P. Maher, A. T. Peterson, J. Soberón, and F. Villalobos (2011). The crucial role of the accessible area in ecological niche modeling and species distribution modeling. Ecological Modelling 222:1810-1819.
Beason, R. C. (1995). Horned Lark (Eremophila alpestris). In Birds of North America Online (A. Poole, Editor). Cornell Lab of Ornithology, Ithaca, NY, USA. http://bna.birds.cornell.edu/ bna/species/195.

Behle, W. H. (1942). Distribution and variation of the Horned Larks (Otocoris alpestris) of western North America. University of California Publications in Zoology 46:205-316.

BirdLife International and NatureServe (2012). Bird Species Distribution Maps of the World, version 2.0. BirdLife International, Cambridge, UK, and NatureServe, Arlington, VA, USA.

Caballero, I. C., and M. V. Ashley (2011). Genetic analysis of the endemic island Loggerhead Shrike, Lanius ludovicianus anthonyi. Conservation Genetics 12:1485-1493.

Clark, P. U., A. S. Dyke, J. D. Shakun, A. E. Carlson, J. Clark, B. Wohlfarth, J. X. Mitrovica, S. W. Hostetler, and A. M. McCabe (2009). The Last Glacial Maximum. Science 325:710-714.

Clement, M., D. Posada, and K. A. Crandall (2000). TCS: A computer program to estimate gene genealogies. Molecular Ecology 9:1657-1659.

Collins, W. D., C. M. Bitz, M. L. Blackmon, G. B. Bonan, C. S. Bretherton, J. A. Carton, P. Chang, S. C. Doney, J. J. Hack, T. B. Henderson, J. T. Kiehl, W. G. Large, et al. (2006). The community climate system model version 3 (CCSM3). Journal of Climate 19:2122-2143.

Delaney, K. S., and R. K. Wayne (2005). Adaptive units for conservation: Population distinction and historic extinctions in the Island Scrub-Jay. Conservation Biology 19:523-533.

Delaney, K. S., S. Zafar, and R. K. Wayne (2008). Genetic divergence and differentiation within the Western Scrub-Jay (Aphelocoma californica). The Auk 125:839-849.

Drovetski, S. V., S. F. Pearson, and S. Rohwer (2005). Streaked horned lark Eremophila alpestris strigata has distinct mitochondrial DNA. Conservation Genetics 6:875-883.

Drovetski, S. V., R. M. Zink, S. Rohwer, I. V. Fadeev, E. V. Nesterov, I. Karagodin, E. A. Koblik, and Y. A. Red'kin (2004). Complex biogeographic history of a Holarctic passerine. Proceedings of the Royal Society of London, Series B 271:545-551.

Drummond, A. J., and A. Rambaut (2007). BEAST: Bayesian evolutionary analysis by sampling trees. BMC Evolutionary Biology 7:214.

Edwards, S. V. (2009). Is a new and general theory of molecular systematics emerging? Evolution 63:1-19.

Excoffier, L., and H. E. L. Lischer (2010). Arlequin suite ver 3.5: A new series of programs to perform population genetics analyses under Linux and Windows. Molecular Ecology Resources 10:564-567.

Excoffier, L., P. E. Smouse, and J. M. Quattro (1992). Analysis of molecular variance inferred from metric distances among DNA haplotypes: Application to human mitochondrial DNA restriction data. Genetics 131:479-491.

Filardi, C. E., and R. G. Moyle (2005). Single origin of a pan-Pacific bird group and upstream colonization of Australasia. Nature 438:216-219.

Floyd, C. H., D. H. Van Vuren, K. R. Crooks, K. L. Jones, D. K. Garcelon, N. M. Belfiore, J. W. Dragoo, and B. May (2011). Genetic differentiation of island spotted skunks, Spilogale gracilis amphiala. Journal of Mammalogy 92:148-158.

Gilbert, D. A., N. Lehman, S. J. O'Brien, and R. K. Wayne (1990). Genetic fingerprinting reflects population differentiation in the California Channel Island fox. Nature 344:764-767. 
Grinnell, J., and A. H. Miller (1944). The distribution of the birds of California. Pacific Coast Avifauna 27.

Hackett, S. J. (1996). Molecular phylogenetics and biogeography of tanagers in the genus Ramphocelus (Aves). Molecular Phylogenetics and Evolution 5:368-382.

Hasumi, H., and S. Emori (2004). K-1 coupled GCM (MIROC) description. In K-1 Technical Report 1. Center for Climate System Research, University of Tokyo, Tokyo, Japan. pp. 1-34.

Hedrick, P. W. (2005). A standardized genetic differentiation measure. Evolution 59:1633-1638.

Hey, J. (2010). Isolation with migration models for more than two populations. Molecular Biology and Evolution 27:905920.

Hijmans, R. J., S. E. Cameron, J. L. Parra, P. G. Jones, and A. Jarvis (2005). Very high resolution interpolated climate surfaces for global land areas. International Journal of Climatology 25: 1965-1978.

Hijmans, R. J., S. J. Phillips, J. R. Leathwick, and J. Elith (2012). Dismo: Species distribution modeling, version 0.8-5. http:// cran.r-project.org/web/packages/dismo/index.html.

Hijmans, R. J., and J. van Etten (2012). Raster: Geographic analysis and modeling with raster data, version 2.0-12. http:// CRAN.R-project.org/package $=$ raster.

Huelsenbeck, J. P. and F. Ronquist (2001). MRBAYES: Bayesian inference of phylogenetic trees. Bioinformatics 17:754-755.

Johnson, D. L. (1977). The late Quaternary climate of coastal California: Evidence for an ice age refugium. Quaternary Research 8:154-179.

Johnson, N. K. (1972). Origin and differentiation of the avifauna of the Channel Islands, California. The Condor 74:295-315.

Klicka, J., G. M. Spellman, K. Winker, V. Chua, and B. T. Smith (2011). A phylogeographic and population genetic analysis of a widespread, sedentary North American bird: The Hairy Woodpecker (Picoides villosus). The Auk 128:346-362.

Knowles, L. L., and B. C. Carstens (2007). Estimating a geographically explicit model of population divergence. Evolution 61:477-493.

Laughrin, L., M. Carroll, A. Bromfield, and J. Carroll (1994). Trends in vegetation changes with removal of feral animal grazing pressures on Santa Catalina Island. In The Fourth California Islands Symposium: Update on the Status of Resources (W. L. Halvorson and G. J. Maender, Editors). Santa Barbara Museum of Natural History, Santa Barbara, CA, USA. pp. 523-530.

Lerner, H. R. L., M. Meyer, H. F. James, M. Hofreiter, and R. C. Fleischer (2011). Multilocus resolution of phylogeny and timescale in the extant adaptive radiation of Hawaiian Honeycreepers. Current Biology 21:1838-1844.

Lester, S. E., B. I. Ruttenberg, S. D. Gaines, and B. P. Kinlan (2007). The relationship between dispersal ability and geographic range size. Ecology Letters 10:745-758.

Losos, J. B., and R. E. Ricklefs (2009). Adaptation and diversification on islands. Nature 457:830-836.

Mundy, N. I., C. S. Winchell, and D. S. Woodruff (1997). Genetic differences between the endangered San Clemente Island Loggerhead Shrike Lanius ludovicianus mearnsi and two neighbouring subspecies demonstrated by mtDNA control region and cytochrome $b$ sequence variation. Molecular Ecology 6:29-37.

Nylander, J. A. A., J. C. Wilgenbusch, D. L. Warren, and D. L. Swofford (2008). AWTY (are we there yet?): A system for graphical exploration of MCMC convergence in Bayesian phylogenetics. Bioinformatics 24:581-583.

Oberholser, H. C. (1902). A review of the larks of the genus Otocoris. Proceedings of the U.S. National Museum 24:801883.

Olson, D. M., E. Dinerstein, E. D. Wikramanayake, N. D. Burgess, G. V. N. Powell, E. C. Underwood, J. A. D'Amico, I. Itoua, H. E. Strand, J. C. Morrison, C. J. Loucks, T. F. Allnutt, et al. (2001). Terrestrial ecoregions of the world: A new map of life on earth. BioScience 51:933-938.

Oster, J. L., I. P. Montañez, W. D. Sharp, and K. M. Cooper (2009). Late Pleistocene California droughts during deglaciation and Arctic warming. Earth and Planetary Science Letters 288:434443.

Paradis, E. (2010). Pegas: An R package for population genetics with an integrated-modular approach. Bioinformatics 26: 419-420.

Patten, M., G. McCaskie, and P. Unitt (2003). Birds of the Salton Sea: Status, Biogeography, and Ecology. University of California Press, Berkeley, CA, USA.

Pearson, S. F., and B. Altman (2005). Range-wide streaked Horned Lark (Eremophila alpestris strigata) assessment and preliminary conservation strategy. Washington Department of Fish and Wildlife, Olympia, WA, USA. http://www.fws.gov/ oregonfwo/Species/Data/StreakedHornedLark/Documents/ SHL-assessment_strategy.pdf.

Pergams, O. R. W., and M. V. Ashley (2000). California Island deer mice: Genetics, morphometrics, and evolution. In Proceedings of the Fifth California Islands Symposium (D. R. Browne, K. L. Mitchell, and H. W. Chaney, Editors). U.S. Department of Interior, Minerals Management Service, Camarillo, CA, USA. pp. 278-288.

Peterson, A. T., M. Papeş, and J. Soberón (2008). Rethinking receiver operating characteristic analysis applications in ecological niche modeling. Ecological Modelling 213:63-72.

Peterson, A. T., J. Soberón, R. G. Pearson, R. P. Anderson, E. Martínez-Meyer, M. Nakamura, and M. B. Araújo (2011). Ecological Niches and Geographic Distributions. Princeton University Press, Princeton, NJ, USA.

Phillips, S. J., R. P. Anderson, and R. E. Schapire (2006). Maximum entropy modeling of species geographic distributions. Ecological Modelling 190:231-259.

Phillips, S. J., and M. Dudík (2008). Modeling of species distributions with Maxent: New extensions and a comprehensive evaluation. Ecography 31:161-175.

Posada, D. (2008). JModelTest: Phylogenetic model averaging. Molecular Biology and Evolution 25:1253-1256.

Rea, A. M. (1991). Vireo huttoni. Geographic variation: (1) Small Pacific coast races. In The Known Birds of North and Middle America, part 2 (A. R. Phillips, Ed.). A. R. Phillips, Denver, CO, USA. pp. 183-186.

Ronquist, F., and J. P. Huelsenbeck (2003). MrBayes 3: Bayesian phylogenetic inference under mixed models. Bioinformatics 19:1572-1574.

Ryan, P. G., L. B. Klicka, K. F. Barker, and K. J. Burns (2013). The origin of finches on Tristan da Cunha and Gough Island, central South Atlantic ocean. Molecular Phylogenetics and Evolution 69:299-305.

Schoenherr, A. A., C. R. Feldmeth, and M. J. Emerson (1999). Natural History of the Islands of California. University of California Press, Berkeley, CA, USA. 
Stamatakis, A. (2006). RAxML-VI-HPC: Maximum likelihood-based phylogenetic analyses with thousands of taxa and mixed models. Bioinformatics 22:2688-2690.

Stamatakis, A., P. Hoover, and J. Rougemont (2008). A rapid bootstrap algorithm for the RAxML Web servers. Systematic Biology 57:758-771.

Swenson, N. G., and D. J. Howard (2005). Clustering of contact zones, hybrid zones, and phylogeographic breaks in North America. American Naturalist 166:581-591.

Warren, D. L., and S. N. Seifert (2011). Ecological niche modeling in Maxent: The importance of model complexity and the performance of model selection criteria. Ecological Applications 21:335-342.

Wayne, R. K., S. B. George, D. Gilbert, P. W. Collins, S. D. Kovach, D. Girman, and N. Lehman (1991). A morphologic and genetic study of the island fox, Urocyon littoralis. Evolution 45:18491868.
Wilson, A. (2008). The role of insularity in promoting intraspecific differentiation in Song Sparrows. Ph.D. dissertation, University of British Columbia, Vancouver, BC, Canada.

Wilson, A., P. Arcese, L. F. Keller, C. L. Pruett, K. Winker, M. A. Patten, and Y. Chan (2009). The contribution of island populations to in situ genetic conservation. Conservation Genetics 10:419-430.

Zink, R. M. (1994). The geography of mitochondrial DNA variation, population structure, hybridization, and species limits in the Fox Sparrow (Passerella iliaca). Evolution 48:96111.

Zink, R. M., and G. F. Barrowclough (2008). Mitochondrial DNA under siege in avian phylogeography. Molecular Ecology 17: 2107-2121.

Zink, R. M., A. Pavlova, S. V. Drovetski, and S. Rohwer (2008). Mitochondrial phylogeographies of five widespread Eurasian bird species. Journal of Ornithology 149:399-413. 